\title{
Bayonet Fencing : An overview of historiography and techniques for French footmen during World War I.1
}

\author{
Julien Garry
}

\begin{abstract}
This article addresses the evolution of French bayonet fencing, teachings and methods over the course of World War I, under both historiographical and technical approaches. After a brief summary of the existent methods at the start of the War, we will explore the evolutions underwent by this Martial Art, brought by the changing nature and warfare and the various inputs of experienced fighter.
\end{abstract}

\section{INTRODUCTION : THE WAR AND THE BAYONET.}

Bayonet fencing, a martial and military art par excellence, was part of the mandatory skills for all French foot troopers when the World War started in 1914. Martial Arts enthusiasts know well that there are rarely random or based on improvisation ; therefore it seems proper to enquire about the state of this practice at the time France went at war, in August 1914, both under an historiographical and a technical point of view.

At the beginning of the XXth century, bayonet fencing methods were included in official regulations published by the Ministry of War (as it was in the previous century). These texts were used as reference works for military instructors for exercise and drill, but also in the training of soldiers : for shooting, for wielding the whole range of weapons that were called to serve, and also for close combat, in which the bayonet was mainly used.

We therefore shall try to review the ensemble of official texts used by the French foot trooper immediately prior to the War, but also those that were adopted during the conflict, up to its end. Of course, these texts are not mere creations of the only XXth century, but are part of a long martial tradition that we shall try to sum up prior to any other thing. Also, there regulations were sometimes commented, discussed and completed by the owners of the Martial Knowledge of these times, i.e. by the experienced veterans and Masters-at-Arms. We whall thus introduce two reference works by these "experts", as related to the official texts.

It seems also necessary to describe the weapon itself, as the main tool to which these methods corresponded: the infantry rifle model 1866 "Lebel", and the associated bayonet. We will see how well adapted to its use this tool is, for shooting and also both attacking and defending in close combat.

1 This is a developed presentation of the workshop which was given during the Eleventh Historical European Martial Art International Gathering of Dijon, on May 12, 2012, called "Practice and Evolution of The French Army Bayonet Fencing during World War I". 
This general presentation of the sources and techniques aims at explaining the undeniable evolution underwent during the War by bayonet fencing: its forms, teaching, goals and overall use in an armed confrontation.

World War I, major conflict that really gave birth to the XXst Century, plunged Europe and the major part of the world in over four years of a bloody conflagration. But it also naturally resulted in major evolutions in things related to warfare, be it from a strategic or technological point of view. And obviously, bayonet fencing was part of these. In France, this martial art, typically associated with the military, was an integral part of the education of the foot trooper since the early XIXth century. From the military instructor to the fencing teacher, and from the strategist to the general, all of them recognized the indisputable necessity for the foot soldier to know how to use correctly his weapon, ultimate protection in close combat.

But with the evolution of materials and equipment over the course of the XIXth century, close combat became less and less frequent, and question was asked of the necessity of continuating teaching this art. Was it sensible to reduce instruction of it, or to keep it only for a chosen elite of veterans - or to forsake it, pure and simple? Yet the Russo-Japanese war of 1905 showed - in addition to bringing improvements to rifles that fighting with the bayonet was still useful, and needed.

Still, such were the questionings among the French military thinkers when WWI started, in 1914. What, then, were the methods and masters known to the French foot soldier at the beginning of the war? What were the tools and techniques used? And when the War of movement became a war of position and turned into trench warfare, how did the practice of bayonet fencing evolve?

\section{BEGINNINGS OF AN ART}

The teaching and practise of bayonet fencing as a true "martial art" was first ${ }^{2}$ theorised, written and published by the German Von Selmnitz, in 1825. His book, Die bajonetfechtleunst oder lebre des verbaltens mit dem infanterie-gewerhre3, was thus the first "fighting handbook", centered upon the bayonet clasped at the tip of the rifle, to attack or defend oneself in close combat. This book, translated into French (MERJAY, 1840, De l'escrime à la baïonnette, ou, instruction pour l'emploi du fusil d'infanterie comme arme d'attaque et de défense), soon became a reference for the teaching of this typicaly military art, and became the basics of German bayonet fencing, and held a line of of writers/successors who soon made up a strong bibliography on the subject, in Germany.

2 As the oldest bayonet fencing manual known as such in Europe

3 VON SELMNITZ, E. (1840) : De l'escrime à la baïonnette, ou, instruction pour l'emploi du fusil d'infanterie comme arme d'attaque et de défense, traduction par MERJAY de Die bajonetfechtkunst oder lehre des verhaltens mit dem infanterie-gewerhre. Petit, Bruxelles. 
In France, although at first the Von Selmnitz method was translated and unofficially endorsed by military instructors so as to improve their troops' skills with blade weapons, French authors soon gave their point of view on the matter. It must be said that the use of bayonet with the rifle was already common, and compulsory for every infantry corps since Marshall Vauban had it adopted in 1703 as a footsoldier's unavoidable piece of equipment... The first of these authors was Alexandre Muller, in 1828, who published Maniement de la baïonnette, appliqué à l'attaque et à la défense de l'infanterie individuellement et en masse ${ }^{4}$ (Handling of the Bayonet, as applied to the attack and the defense of the infantry, alone or en masse). In 1832, Paris Military Gymnasium instructor Joseph Pinette unveiled his own method l'Ecole du tirailleur ou maniement de la baïonnette appliqué aux exercices et mancouvres de l'infanterie ${ }^{5}$ (The Sharpshooter's School or Handling the Bayonet applied to infantry's exercises and manœuvres), in a book which would be published and republished many times, and would became the French reference on bayonet fencing for more than half a century : interpreted, simplified or detailed by many authors.

It was about that moment that the French Military Authorities considered "officialising" the teaching of this art. Thus was included in the first place, in l'Instruction provisoire sur l'exercice et les mancuvres des bataillons de chasseurs à pied (Temporary Teachings on exercises and manoeuvres of the bataillons of chasseurs à pied) in 1841, with a chapter featuring a full bayonet fencing lesson, derived - partially at least - from Pinette's method 6 .

For the first time, an official publication from a War Ministry (or its equivalents, according to the governments' context : Republic, Kingdom or Empire) acknowledges the usefulness of this art and its teachings for the soldiers, and includes it to the regulations already in place concerning manoeuvres or exercises of the different army corps. This 1841 publication was the first step of the parting between what we could call the "official" methods (from ministries, which do not bear any signatures, or only the signature of the Minister of the time, and are aimed only for the military instructors), and the "private" methods (from independent authors who wanted, for various reasons, share their opinions and reflexions on the subject, sometimes for military, patriotic reasons in order to help the army teaching their cadets, or simply for the martial sake of the thing, where bayonet fencing is an original alternative to be practised in a salle, instead of the foil, saber or sword...).

\footnotetext{
4 MULLER, (1835) : Maniement de la baïonnette, appliqué à l'attaque et à la défense de l'infanterie. Moreau, Paris.

5 PINETTE, J. (1837) : Ecole du tirailleur ou maniement de la baïonnette appliqué aux exercices et manœuvres de l'infanterie. Gauthier-Laguionie, Paris.

6 A lineage asserted by A.J.J. Posselier, said "Gomard", another slightly later author, which can be checked by comparing the two methods : the similarities between guards, names, succession of lessons and teachings are indeed very high
} 


\section{Bayonet and Screwdrivers}

If nowadays the Lebel Rifle is part of historical relics, many a model 1886 or 1915 bayonet remains in service: in old workshops and tool-cases of many grand-fathers. As a matter of fact, at the end of the war, demobilised soldiers came back home with part of their gear, and many, lacking proper tools or simply out of recycling, turned their bayonet into a screwdriver.

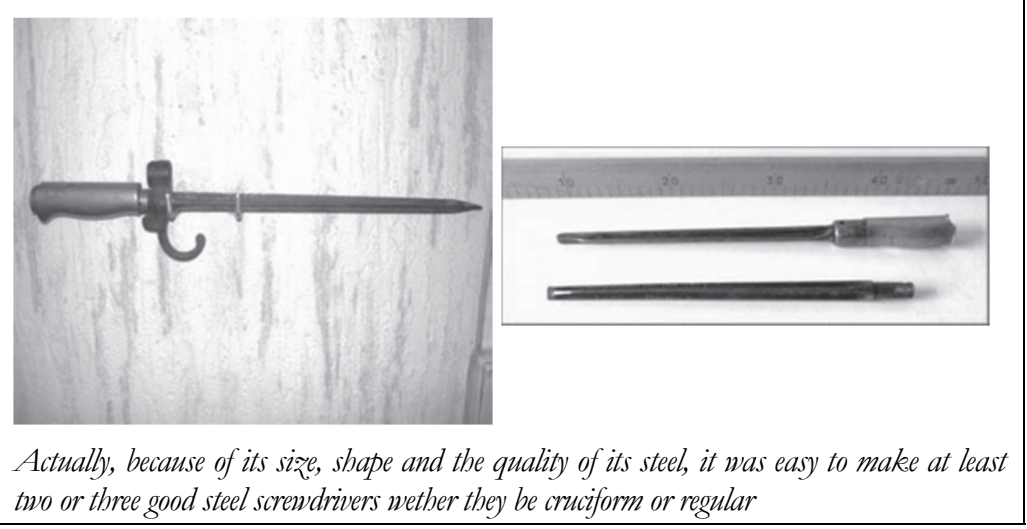

There are many cross-overs between these methods, and although we can distinguish between them obviously ${ }^{7}$, the more or less direct inspirations and references between these two categories are many. This division between "official" and "private" methods would last until the era we are studying, which spans from the beginning of the $20^{\text {th }}$ Century until the end of the Great War :

As the "private" methods are many and numerous ${ }^{8}$, and since it is nearly impossible to estimate their concrete use by soldiers and their teachers, we will stick to the "official" methods, those which must have been taught during the French soldiers' training". However, we will make two exceptions :

- Capitaine Dubois's method, a bayonet fencing instructor from the colonial infantry who published in his name an applied commentary and pedagogy about the official methods in use at the beginning of the war;

\footnotetext{
7 The differences between these two categories being : - the signature of such or such private author as opposed to the lack of signature in official methods. - the "private" books are almost all manuals dedicated exclusively to the sole subject of bayonet fencing, while "official" methods are almost always included in books containing other military instructions, such as "manoeuvres regulations", "physical education regulations" or manuals aimed at the instruction of officers 8 A list trying to gather all known French methods, both "private" and "official", is available on the De Taille et d'estoc forum.

${ }^{9}$ Instructors were of course free to read or find inspiration in any available reference and book in order to build their training programs, one cannot be certain of their degree of knowledge of the private methods, and therefore of the proportion taken by the "official" techniques in the course of their training
} 
- Capitaine Hassler's book (with Emile André), another soldier who published to enhance and contextualise this same method. 10

Both these men, although they didn't write on behalf of the government, introduce us with texts which cannot be separated from the War Ministry, since they are both based upon the Manoeuvres regulations of April 20, 1914, which was published and ordered by the War Minister de Noulens.

"Without agreeing to the barbarous Souwaroff's opinion: "The bullet is mad, only the bayonet is wise", I call for this weapon the title which General Monteculi would only concede to the lance : the bayonet is the Queen of blade weapons."

J.Pinette, 1837, l'Ecole du tirailleur ou maniement de la baïonnette appliqué aux exercices et mancouvres de l'infanterie

\section{THE ART AND THE TOOL}

During World War I, the French soldiers made use of many weapons, scores and scores of weapons, of all sizes, of all classes, blades as well as guns, from the $75 \mathrm{~mm}$ cannon to the Officier Sabre, from gases to Trench knife...But the most emblematic of all those tools, and the most lethal is the simple infantry rifle of the Land Forces : Infantry class rifle $1886 \mathrm{~m} 93$ aka "Lebel". It is this gun, in use since the end of the $19^{\text {th }}$ Century, with a walnut stock, a steel barrel and whose magazine and barrel could have a load of load ten bullets, which was used in the Great War by the soldiers. Not only to shoot with, but also to defend themselves, with the bayonet locked on the barrel.

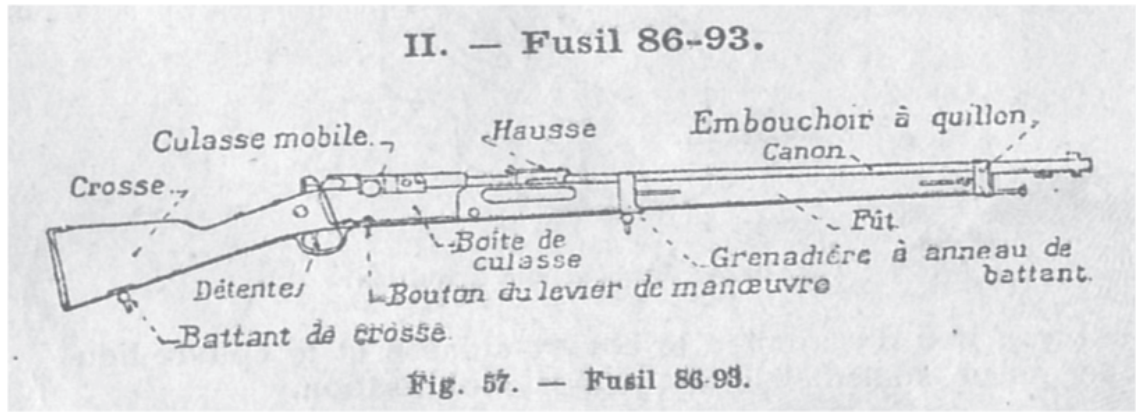

Rifle mdl 1886 m 93, taken from : Manuel du gradé d'infanterie 11

The bayonet used with this gun is simply called "Epée-Baïonette modèle 1886" (Swordbayonet 1886 pattern). It is a "sword" for a pragmatic reason : before, with the 1822 pattern, or even older ones, the bayonet was locked onto the barrel by some sort of washer, called

10 HASSLER \& ANDRE, E. (1916) : L'arme blanche dans la grande Guerre, Méthode simplifiée de Baïonnette. Floury, Paris.

DUBOIS, M. (1916) : La baïonnette, à la française ! Techniques élémentaires. Lavauzelle, Paris.

11 Ministère de la Guerre. (1926) : Manuel du gradé d'Infanterie. Lavauzelle, Paris. 
"socket", which was wrapped around the barrel to keep the bayonet into place without it obstructing the barrel. Then, it was considered that the bayonet could be held with the hand. A handle, more and more sophisticated, was thus designed, and so was a new attachment system. Thus began the time of saber-bayonets, which were used at the tip of the gun, and in the hand of the fighter when needed. With the 1886 pattern, the bayonet took another shape : the blade became cruciform, and therefore lost its edge. It was thus no longer used as a "saber", but as a "sword". Like the fencing swords, the "épée", the blade at the end of the handle could only be used for thrusts, with just a difference : sword-bayonet was really design for kill (so more as the oldest medieval sword).

\section{The Filloux System 1915}

When the Great War was stuck into warfare, and became a war of position, the soldiers had to use all of their ingenuity to go through shell holes, barbed wire, traps and mines which were all over the no-man's-land. It was with this in mind that the Filloux system was designed: once the bayonet was locked at the tip of the gun's barrel, it allowed the soldier to cut the barbed wire which was in his way:

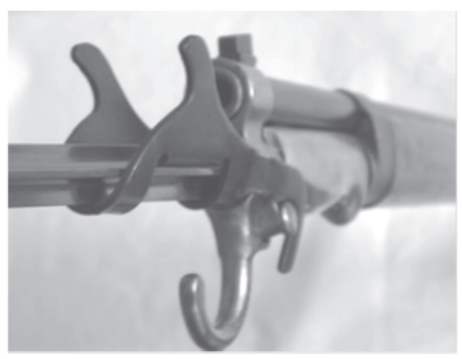

The barbed-wire is stuck in the mecanism's "ears", and is thus perfectly in line with the barrel: the soldier now only has to shoot to cut the wire and go through...

This Sword-bayonet is composed of :

- A handle, $92 \mathrm{~mm}$ long, made of metal which varied, according to the design : brass, for the most part, but some were made of steel, cast iron, and nickel silver for the elder designs. This handle is grooved to be attached on the barrel.

- A cross-guard with a push-button and a little socket, both intended to lock the bayonet on the rifle. The croisière (cross) also sports a short rounded quillon which bears the gun's serial number. In 1915, because of the shortage of metal, and of the fighters thought it useless and sometimes cumbersome (mainly on the no-man's-land, where it would get caught in the barbed wire), the bayonet was made without a quillon. It thus became the Bayonet $1886 \mathrm{~m} 1915$ pattern. Nevertheless, the presence or not of this quillon doesn't change anything regarding its fencing.

- A $52 \mathrm{~cm}$, cruciform blade, with a $15 \mathrm{~mm}$ diameter, bearing the weapon manufacture's stamp. 
The rifle and this weapon assembled gave a $1825 \mathrm{~mm}$ long tool, weighing, if loaded, $4.890 \mathrm{~kg}$, which made it a long and heavy weapon! Those characteristics, explains Capitaine Dubois ${ }^{12}$, gives the bayonet fencer an advantage over the sabre-player, because of its reach, and an advantage over the lancer by the power gained on his strikes because of such a heavy weapon.

\section{L'épée-baīonnelle.}
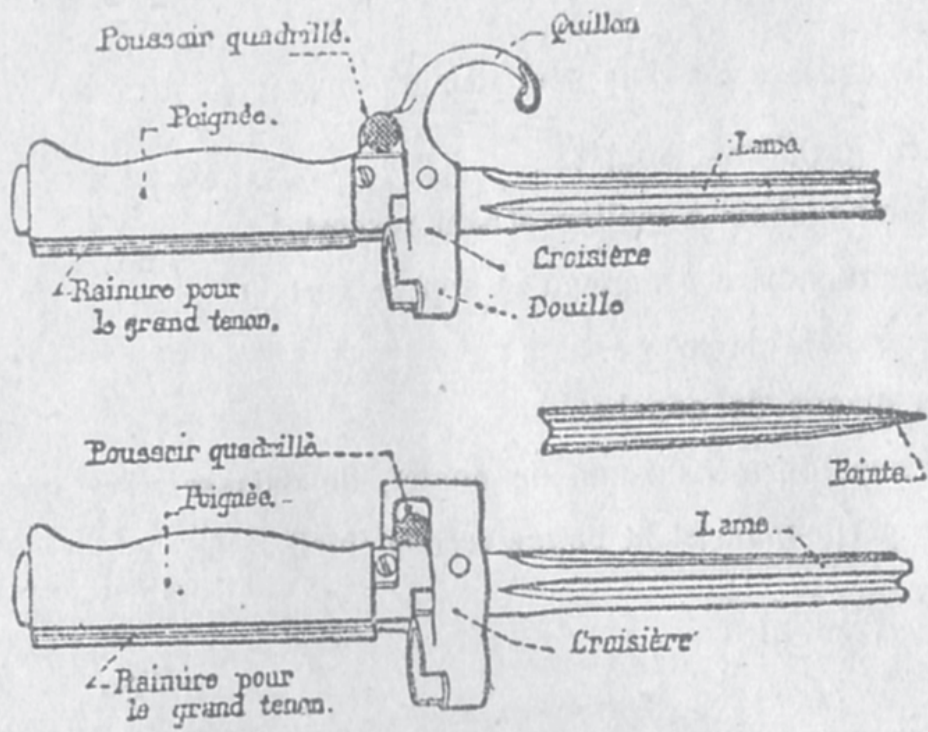

Fig. 55. - Epée-baïonnette.

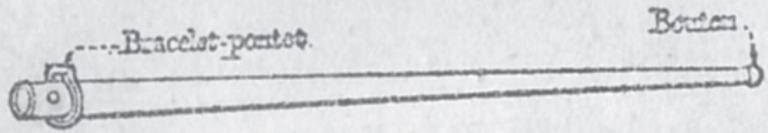

Fig. 56. - Fourreau.

Épée-baïonnette mdl 1886, \& 1886 m 1915, from Manuel du gradé d'Infanterie 13

\section{IV. « ROSALIE »}

If the cute name «Sword-bayonet modèle 1886 m. 1915 » doesn't ring any bell, it might probably be because it has been, nowadays, forgotten, and replaced by the nickname "Rosalie". This slightly ridiculous, name comes actually from one of numerous patriotic songs from artist Théodore Botrel, which was written and broadcast on Radio during the War. Nevertheless, if this name is widely used and associated with the weapon today, it was almost unknown on the front line, because of the lack of radio sets, or just

\section{DUBOIS ; ibid}

13 Ministère de la Guerre ; ibid 
lack of interest for the song, but mostly because none of the fighters who had ever heard shouting the order "Fix Bayonets!" would have found it logical to give a name to this so dreaded weapon, and even more so to call it "Rosalie"...

Rosalie it is your story

That we sing to your glory

- pour some drink! -

As we empty our kegs

Let's drink!

Rosalie is so pretty

That Rosalie's lovers

- pour some drink! -

Are at least two, three millions.

Let's drink !14

Rosalie is elegant

Her tight sheath dress

Covers her up to the bilt

But she's irresistible

When, dreadful, she appears,

Naked : bayonet 15

Under the light sky of France

Of the Sun of Good Hope

She seems to be the ray

She loves to go dancing

When, to give the pace,

The cannon had started

The polka that she does

Is done at charging pace

With drums and trumpets
It the midst of battle

She pierces and stings and cuts

Cover high and thrust deep

One must see them routing

The boys from Lembourg an'Baden

Bavarians and Saxons

Rosalie nails them to the plain

They had it, already, in the groin

In the kindey they'll soo get

All white, she's on

But at the end of the game

She's all coloured vermilion

So red and pink

That we baptised her

"Rosalie" in unison

"Rosalie", glorious sister

of Durandal and Joyeuse [Respectively the swords of Roland and Charlemagne]

Support our fame

Be without reproach and withour fear ${ }^{16}$

And with the impure blood of Boches

Fill our furrows!

We thirst for revenge

Rosalie! Give France

Glory in full kegs!

Lyrics an music: Theodore Botrel, 1914. Also sung by Eugénie Buffet note: chansonmarche à l'honneur de la baïonnette, sur l'air de "La Fanchette" (Botrel, 1895)

"Our bayonet, with its center of gravity under the lever, on the limit of the first third of the weapon's lentgh, is a "well in hand "two-handed sword."

Capitaine M.Dubois, 1916, La Bä̈onnette, à la française

\section{WAR OF MOVEMENTS, WAR OF POSITIONS}

At the beginning of the year 1915, when the initial war of movements became a war of positions, the context of use of the bayonet changes, and so does the associated fighting

14 the "pour" and "drink" verses being repeated all over the song, we will not write them each time

15 [there's an untranslatable pun here : "let's bayonet"]

16 [The motto of Bayard, another famous French knight] 
techniques. Indeed, if using edged weapons seems easy and natural when charging the enemy, the latter becomes less obvious when (close) combat takes place in a rough and difficult terrain made only of barbed wire, trees smashed to stumps, shell craters, and corpses. Still, not minding these new factors, French official regulations remained the same, and the standard was the bayonet charge : before every assault, officers would order to fix bladed weapons on the rifle. After all, even if aiming is slightly affected by this extra weight at the end of the barrel, long-range shooting was still a rare occurrence. Moreover, loading and ammunition didn't change, and with a maximum of ten cartridges (and often less due to lack of supplies), the soldier was rapidly left with an empty gun, and no time or means to load it. There is also another, psychological, factor: the presence of the live blade encourages the soldier, and gives him confidence in his arms - something often just as important, and effective, as the arms themselves.

However, changes brought by this war of positions are significant. In addition to the still possible, common situation when soldiers face each other in the no-man's-land or in a trench, new possibilities appear in which fighting takes place on different ground levels, between soldiers in or out of a trench or a crater, or in narrow tunnels limiting motion range, and so forth...Thus methods and techniques have to adapt and evolve, as it is necessary to provide the soldier with the best solution for every situation.

\section{The « official » methods used during the Great War}

\section{December 31904 Decree about regulations on infantry manoeuvres ${ }^{17}$ :}

This handbook, ordered by War Minister Emile Loubet, includes - in its chapter "The Soldier's School" - a bayonet fencing lesson. This lesson follows the teachings of former rules, using their traditional "guard", and the main attacks and parries , but simplifying the text, removing less frequent attacks and parries, as well as the description of the exercises aimed at teaching the techniques, as well as the developed strikes $^{18}$.

This method, used at the beginning of the War, would constitute the basic knowledge of fencing for professional soldiers.

Here is how it was composed :

\section{Guard position :}

Where we describe this guard, similar to the one in effect until now. It is taken like this :

17 Ministère de la Guerre. (1904) : Décret du 3 décembre 1904 portant règlement sur les manœuvres de l'infanterie. Berger Levraut, Paris.

18 "Developed", or "compound" strikes : we shall use these terms to describe a succession of attacks, returns on guard, parries and counter-attacks more or less intricate, as can be used in situation by a soldier facing an experienced opponent. The "by-heart" replaces in that case the adaptive capacity of the good fencer lacked by most soldier, and can also dampen the panic felt when facing the enemy, which can affect even the best fencer of the regiment and prevent him from acting and thinking according to the Art when the time comes 
The right foot is placed a little step behind the left foot, with the "jarrets" (back of the knee) slightly bent, the body weight evenly matched on both legs.

The right hand is holding the rifle by the handle, and is placed against the body, leveled with the right hip, the left hand is holding the rifle under the grenadière, the swing swivel, (see the riffle schema in "The Art and the Tool") a thirty centimetres ahead of the right hand, is directing the le tip of the bayonet towards the opponent.

\subsection{Footwork}

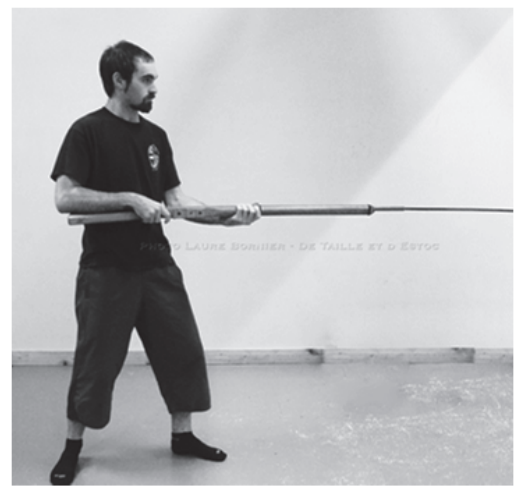

«La garde »

Where we describe the way to move while in guard, how to rotate, make one or more steps, that is to say : Facing right or left, one step forward or backward, or a double step forward or backward.

The rotations are made on the left heel (which means the front foot).

The action to switch foot (that is to say putting the rear foot at the front) is called "step", finishing this movement by a second "step", in order to get back into the first position , but more forwards (or backwards) is called "double step".

\subsection{The Attack}

Only one universal attack is described in this section, performed from the guard: the arms are thrown forward, with the barrel upwards, and a slight lunge on the left foot, as to thrust the opponent. This attack is called "Pointez".

\subsection{Parries}

Here are explained the ways to defend against the attack described above, wether on the right or left : by lifting the end of the weapon and thus oppose the opponent's strike. One can also parry an attack from above by raising both arms to cover with

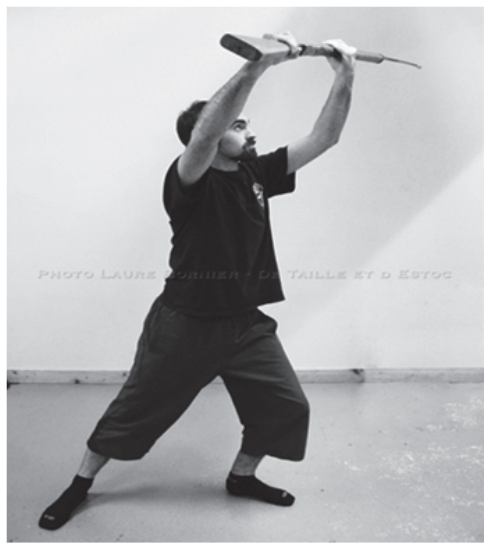

«En tête » the rifle (keeping the point forward to maintain the threat), in a parry called "en tête". This method is made by these four parts, simply, and without any detail, and is therefore no more than a general guide, as compared to the previous versions contained in the 
manoeuvres regulations of 1870, 1875, 188419 etc which detailed more attacks, parries, sometimes other guards, or ways to face other weapons or troop types (like horsemen).

Nota Bene : in 1902 General L. André, then Minister of War, proposed a tentative regulation named Réglement Provisoire...in which is described a somewhat more complete method, elaborating on the previous traditions./ The December 1904 version, a year later, however kept little of the $1902^{20}$ proposal. This change can be attributed to the replacement of L. André by Emile Loubet. The differences in points of view from these two ministers, and their subordinates and advisors, on the usefulness of bayonet fencing (influenced, of course, by the historical context) are certainly the reason behind this important reduction of the teaching.

"The sword fencer faces but a single opponent, placed square in front of him, and whose moves he watches easily; the rifleman, on the contrary, is dommed to face enemies armed with a variety of weapons. He may have to fight a horseman armed with a sabre or spear, as well as a footman with a rifle, and must be prepared to face these possibilities."

Gomard, l'escrime-à-la-baïonnette, 1917

\section{The Règlement de manœuvre d'infanterie du 20 avril $1914^{21}$ :}

Under the Ministry of J.Noulens, the regulations of 1904, deemed too laconic, appearing as lacking or unfit to the current military situation ${ }^{22}$, is replaced by the regulations of April, 20, 1914, repeating the main body of the text, but developing on almost all chapters composing it.

The soldier's school is not forgotten, and the section dedicated to bayonet fencing and its teaching is also given more detail, even though the basis remains the same :

\subsection{Guard position}

There is almost no change from the previous version, except for the placing of the hands and the barrel, more detailed : (the right forearm against the ammunition belt, the

19 -Ministère de la Guerre. (1894) : Règlement du 29 juillet 1884 modifié par décision du 15 avril 1894 sur l'exercice et les manœuvres de l'infanterie. Baudoin, Paris.

-Ministère de la Guerre. (1875) : Règlement du 12 juin 1875 sur les manœuvres de l'infanterie ; avec un rapport à $\mathrm{m}$. le Ministre de la guerre. T.1-2. Imprimerie Nationale, Paris.

-Ministère de la Guerre. (1870) : Nouveau manuel de la Garde Nationale sédentaire, contenant les lois des 10 août 1870, 15 mars, 20 mai et 12 juin 1850, l'école du soldat, l'école de peloton, la manœuvre du fusil Chassepot, du fusil dit à tabatière,du fusil à percussion. Barbou, Limoge.

20 Ministère de la Guerre. (1902) : Règlement provisoire sur les manœuvres de l'infanterie du 8 octobre 1902, Chapelot, Paris.

21 Ministère de la Guerre. (1914) : Règlement de manœuvre d'infanterie du 20 avril 1914.

Fournier, Paris.

22 The instigation of a three-years military service also allows to deepen the content of military instruction, the soldiers having then more time to receive formation 
upper barrel turned towards the left side, the lever at a $45^{\circ}$ angle - article IV, paragraph 122 ; "on guard"). It is also precised that left-handed fighters can be trained in a left guard, thus favouring efficiency.

\subsection{Footwork}

It is explained that footwork are performed to gain or break measure, which is itself defined, as well as voiding and parrying. A foot not gives "measure" as "the farthest distance at which a man can reach his opponent with the bayonet".

The principles don't change, but the motions are better described, and follow-ups of steps and pivots are also given as examples of possible martial moves.

\section{The queen of adaptation}

Many an armed corps, or a specific regiment, or troops deployed on a specific battlefield, had their 1886 pattern bayonets modified:

Users of the Berthier rifle (1907 / 1915 pattern, the second most frequent french gun in the trenches after 1915) thus use a shorter version of the Lebel bayonet. The cycle corps of the Army, so as not to entangle their weapon in the wheels of their bicycles, als had their blades shortened. In the trenches, before the "Trench Knife" became reglementary, many a "Poilu" modified his weapon by bimself, by shortening the blade, cutting off the quillion, or sharpening the weapon so as to adapt it to the close distance encounters.

One captain named Daudeteau designed an experimental rifle in 1895 and adapted 1886 pattern bayonets to it. Only 10000 were made, many of which were used with Remington or Mauser rifles after the Daudetean prototype was abandoned. Other retractable bayonets, were developed for training.

In Indochina, several French troops equipped with the 1902 pattern rifle (such as the Foreign Legion, but also Vietnames volunteers among others) used a modified version of the 1886 patterm bayonet with a shorter handle and ocket adapted to the 1902 gun. This weapon, also used by the Gendarmerie, is called 1890/1902 pattern : it is only in 1912 and for the troops on Indochina that it was shortened by $12 \mathrm{~cm}$.

This weapon, so simple in its composition, was therefore adaptable and usable in every fighting situation, which can explain its long period of use (from its creation in 1866 up until the 1960s in France, but even later by Afghan rebels equipped by France to fight against the USSR, who kept the use for this weapons years after the end of this latest war).

\subsection{The attack}

The basic strike, the "Pointez" (Point!), remains valid, but is nevertheless declined twice, so as to offer the soldier more choices facing opponents more or less remote :

- First variation : you let the left hand slide along the barrel to meet the right hand, thus gaining some reach, but loosing a bit of accuracy.

- Second variation, called "Lancez" (Throw!), consists in letting go of the left hand to reach an even further point, but again, loosing accuracy and gesture stability.

The lunge is mentioned as part of the movement, but must not be overcommitted. 


\subsection{Parries and Ripostes (strike back) :}

The chapter of the old method - which was incredibly short and unaccurate - is widely developed, and the notion of riposte (strike back) is mentioned .

Several choices are possible, for the fencer, in case of an opponent's attack:

- -The "Battez" (Beat!), an action which consists in violently throwing the opponent's point off the line of attack with a sharp and powerful movement, while being not too wide, so as to keep the threat on the opponent.

- - The "Opposez" (Confront!), which consists in meeting the iron so as to feel the opponent's weapon while maintaining a strong pressure.

- -The "Dégagez" (Move away!), which could be defined as a "cavation", common in sword fencing and which allows to switch the attack line by going under the opponent's point.

In this part compound movements are mentioned, mixing different parries with attacks or ripostes, as well as the possibility to parry a horseman's attack, especially by raising the weapon and the hands. This movement replaces the "en tête" (head guard) from the 1904 version.

\subsection{Using the stock}

A new part, as much for the 1904 rules than for the older ones, approaches other ways to make the opponent more vulnerable, by using the weapon or the body, moving the stock forward, hitting on the side or to the front with the stock, or by using kicks, punches, pushes, etc.

This short chapter offers thus new opportunities for the fighter to use, and largely develops the duel, improvising and resourcefulness skills for the soldier trained with these principles.

An other chapter of the book (paragraph 57, "bayonet fighting") defines the role of the instructor in the teaching of this art, as well

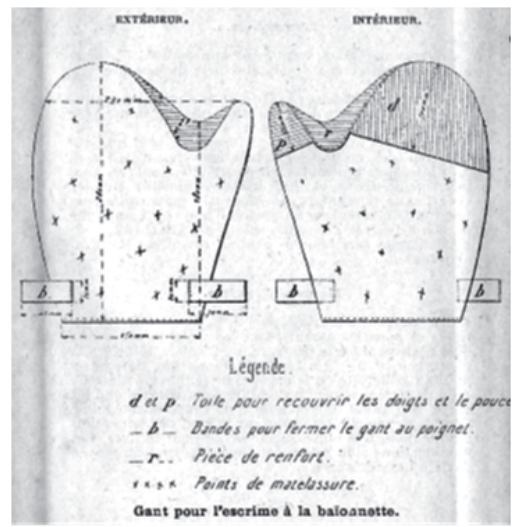

Gant d'escrime, in this manuel, page 136. as the means used for the teaching and the improvement of soldiers: exercises with dummies, individual or group exercises, with or without protections ${ }^{23}$, during competitions or not, in the manner of tournaments. Thus, it is not part of the method,

23 The description of the equipment used for bayonet teaching or competitions (see gloves, ) as wells the organisation of tournaments is very short in the 1914 regulation, but far more detailed and illustrated in the "Règlement d'éducation physique". Page 136 "Annexe III"

Ministère de la Guerre. (1914) : Règlement d'éducation physique du 21 janvier 1910, mis à jour le 1er juin 1914. Lavauzelle, Paris. 
nothings which looks like martial techniques, but rather like the best way to teach them, and the tools to use for succeeding in doing so.

All those evolutions lead to the former method to become at last a complete and finite system, covering most of the "fencing" situations which one might encounter, whatever the enemy and his duellist skills. The description, more or less precise of the ways to train men also allows the instructors in their task. It is then possible to imagine that these soldiers' skills in this "martial art" (in the first sense of the term) are quite important and certainly above to those of their predecessors.

This must be toned down, though : there are many hints to "digressions" in the 1904 method, showing that the method left room for the instructor's imagination, who could then enhance the handbook's "basics" with techniques based on his personal experience.

"The fire power has become so important that it was thought it would suffice on its own to
make the difference on the battlefield. It was well thought that there would still be threats of
bayonet charges, but, at the very least, that there wouldn't be close combat, nor melee
anymore... The Russians and the Japanese proved us to be wrong, and that, as long as will
exist on Earth men with Death in such high contempt, the decisive strike will be brought
about by the bayonet."
Capitaine Serge NIDV INE, "La Bä̈onnette", 1907

An exemple :

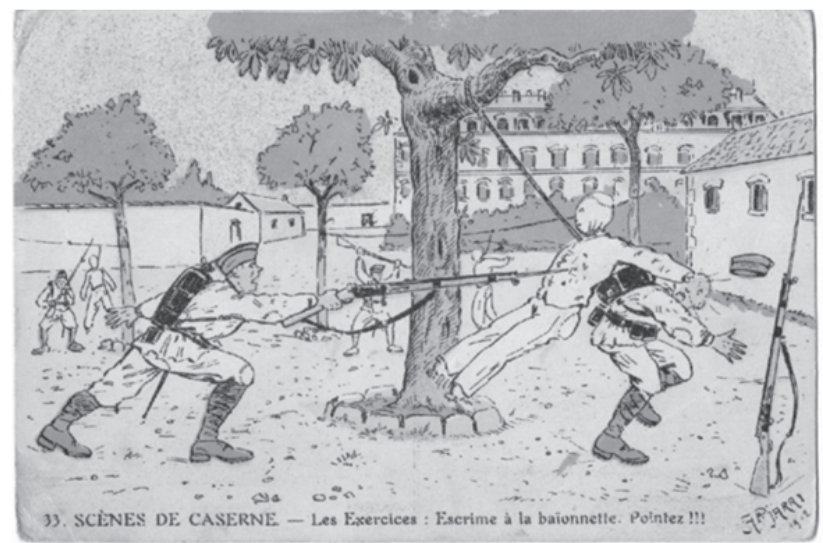

This postcard from 1912 (i.e. before the reforming of the method) shows a casual barrack scene, about the learning of bayonet fencing. Once passed over the humourous tone of the card, it can be noticed that the soldier is performing a perfect exemple of the "coup lancé", with a lunge, on a dummy: however, if the lunge, or training with dummies is part and parcel of the enforced rules, the "coup lancé" in itself is not on the list, the only attack described being the first version of the "Pointez!", in which both hands stay in place on the rifle.

If the author of the artwork could witness this type of strike, it probably means that the instructor or instructors had implemented it in their training program, surely based on their memories of the former rules of bayonet-fencing in which this movement was 
present. This type of information can lead to think that the adaptation skill of the 1904 rules (that is to say its tendency to let instructors to add whatever they wished to the official method) was superior to the 191424 , in which it was clearly stated that the sole content of the regulations, without any addition, had to be taught to the soldier.

\section{The Fighter's physical training, September $1,1918^{25}$ :}

This little leaflet published in 1918 is a global, and less formal, reprint of the Pbysical Education Rules of January 21, 1910, updated on June 1, 191426, while developing the chapters on the larger military application on fighters' physical activities: heavy weapon(s) transportation, fencing, grenade-throwing, etc.

The chapter on bayonet fencing is thus greatly developed. There can be found the great principles from 1914, while developing the content further.

\subsection{General Rules.}

In this chapter are mentioned a huge amount of generalities and advices to fencers and instructors :

- Advices to soldiers to defeat an opponent :

- who isn't on his guard, who is, as a consequence, on first sight, a bad fencer : he must be surprised, hitting quick and strong.

- who his on his guard, and thus looks well-trained, in this case, ranged strikes are to be advised, and short of this, be extremely careful to avoid the double strike, and use all of one's art and craft to succeed.

It is written in this paragraphs all the qualities the fighter must show (i.e. swiftness, violent attacks, activity "pushed to the highest point", nimbleness, willpower, knowledge of the opponent's vulnerable parts, getting back in guard position swiftly, stamina, breath, ...)

- A few common places on the practise of this art, on the consequences of training, the exhaustion caused by the engagement, the main difference with the other sorts of fencing being fighting with several enemies in sometimes a very short time, and not one-on-one as is the case during a duel in a gym...

- Recommendations on which gear to use, and on the layouts of the place where to train.

The recommended gear :

- A rifle with a slide-in bayonet for the training (or simply the rifle with a sheathed bayonet (this option being more dangerous).

- Fencing masks.

24 Ministère de la Guerre 1914 ; ibid

25 Ministère de la Guerre. (1918) : Entraînement physique du combattant, du 1er septembre 1918, Imprimerie Nationale, Paris.

26 Ministère de la guerre 1910/1914; Ibid 
- Gloves (especially for the left hand).

- More or less advanced dummies/bag, on the ground or hanged (see fig. 1 17).

- Sticks with stamps, others with discs, length : $1.80 \mathrm{~m}$, diameter ; 15 to $20 \mathrm{~mm}$ $(\text { see fig. } 2)^{27}$

Place layout :

- A flat ground for the beginning of the training (such as a gym)

- A rough ground, with trenches, tunnels and scaffoldings to train in all conditions.

- Training in forest or varied grounds is recommended.

"The only weapon, which, from the hand to hand fighting point of view, would have been superior to a rifle with a locked bayonet, is the two-handed sword. However, this dreadful, and assuredly well conceived weapon, hasn't been used anywhere, for a long time."

Adolphe Corthay, Petit traité d'escrime à la baïonnette, 1889

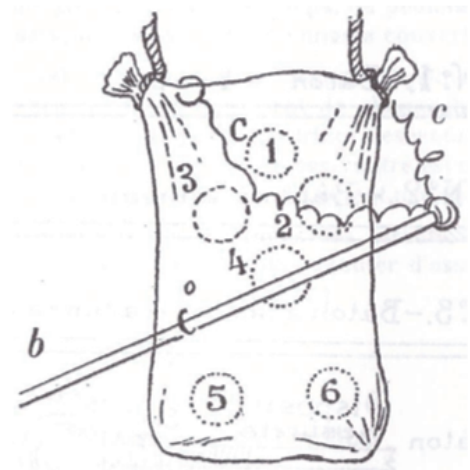

Fig. 1

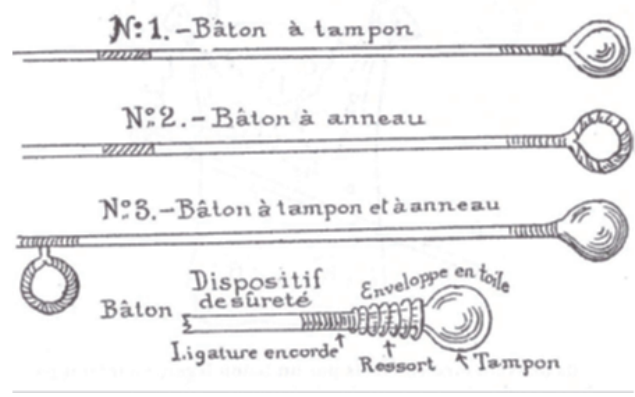

Fig. 2

\subsection{Description of the Strikes}

\section{Charge paces and guards.}

In this section, guards and footwork are mixed. The steps remain the same as in the previously mentioned methods. The only different matter, aside from the rest, is the moving speed variation. Measure step is still an important notion.

On the other hand, as far as the guards are concerned, this method is way more complex and differs from the former ones.

No less than five different guards can be found :

27 These illustrations are from a manual... by an unidentified author, maybe a local antenna of the ministry of war. The content of this book, from 1917, will be the basis upon the 1918 method would be built.

Ministère de la Guerre. (1917) : Instruction pour le combat à la baïonnette et le lancer de grenade. Lacour, Besançon. 
- The first one is the one used in the other two methods. Here, it is called "en garde à droite" (right guard).

- The following is a variation on the first, the evolution from the guard for the left-handed, with the left hand forward, which can be used under any circumstance, and this,even for a right-handed person. It is simply called "en garde à gauche" (left guard).

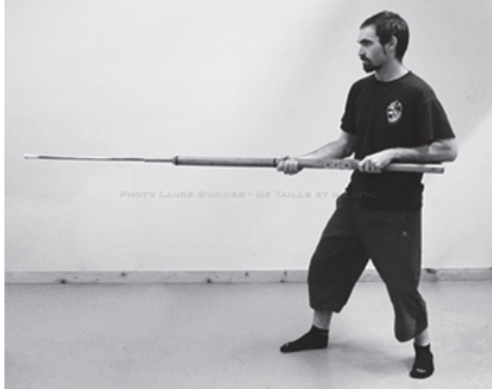

«En garde à gauche »

- The third one is a variation on the right guard : it is the "garde courte à droite" (short right guard). The rifle is held as in the right guard, either by putting the hand backwards or forwards on the barrel, and allows the fencer not to give way to the opponent's whipping and beating, and on the contrary, to take the upper hand thanks to the parrying speed.

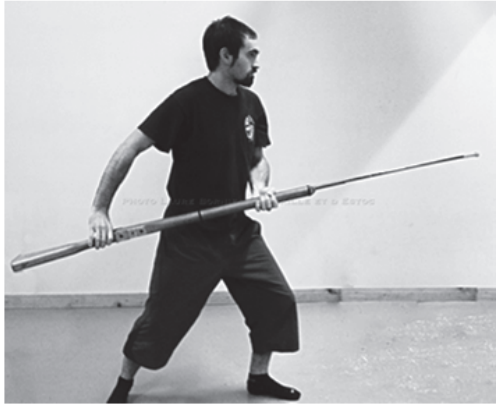

" Garde courte à droite", first form (with the hands further apart)

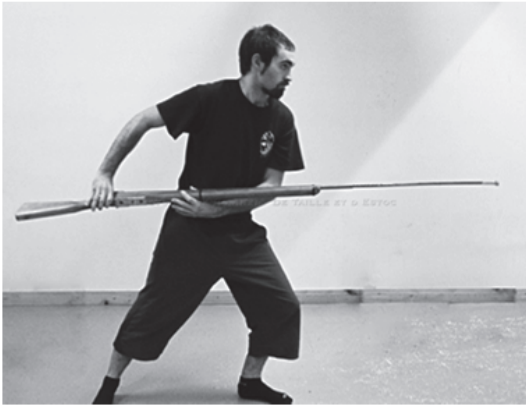

"Garde courte à droite », second form (with the hands backwards)

"It has been told and uttered beautiful tirade about the bayonet. Many times has it been illspoken of, usually, without further more solid grounds from one side or the other, for in the dithyrambs, it is the "typically French" bayonet which is mostly celebrated, whereas the haros go for the "useless weapon". However, the bayonet-fighter value is measured up to his training, not to the latitude and longitude of the place where he was born."

Capitaine M.Dubois, 1916, La Bä̈onnette, à la française! 
- The "Garde courte à gauche" (the Short Left Guard), the same on the other side.

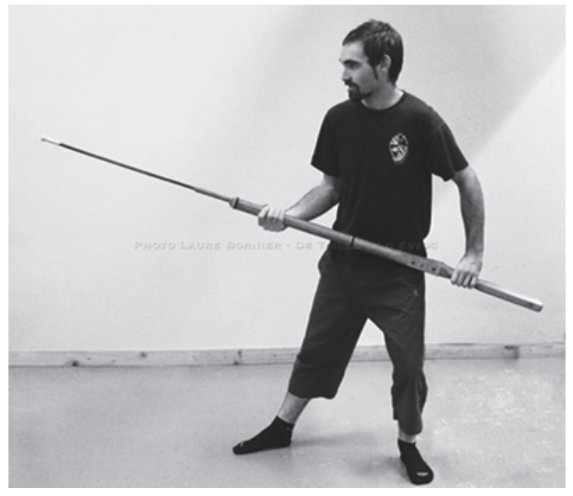

" Garde courte à gauche », first form.

- The "garde en dessus" (the Upper Guard) : the return of the "head Guard" from 190428, which is now used not against horsemen, but during fights in a trench or a narrow tunnel.

An other situation is mentioned: when a soldier finds himself stuck behind an obstacle, or in a shelter, he can hold his gun straight in front of him, on a vertical axis, with his two hands, so as to parry and take a guard.

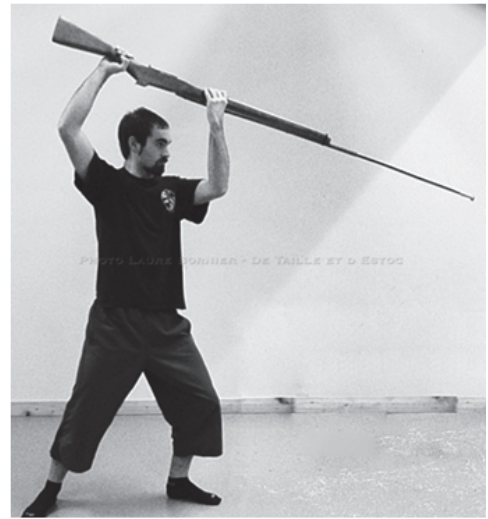

«Garde en dessus »

\section{The attack}

The three attacks from the 1914 method, as well as stock or body strikes are still valid and are not described at length : it is here mostly mentioned compound strikes, such as the "battez large-coup de crosse-pointez?" (Beat wide-strike from stock to point!) to mention one. Those strikes mix the common strikes from previous rules, from the five abovementioned guards, with the parades also recovered from those methods.

In this chapter, they describe how to take away the weapon from a dead body, by putting your foot on the corpse and pushing down, pulling the point from the corpse.

28 Ministère de la Guerre ; 1904 ; ibid 


\section{Weak points}

Here are described the priority targets on the body of the opponent, which consist in : the face, the neck, the heart, the thighs, and, failing those before mentioned targets, the advanced arm.

\section{Beatings, parades and riposte}

In this method, the beatings are part and parcel of any parade, and the ripostes must be systematic. This chapter is not much developed, most of the strikes having been described in the compound-strikes of the "Attack" section.

\section{Half hand-to-hand strikes}

This section details the same strikes, from the two short guards, thus evoking the possibility to land barrel strikes, lest be the point be used.

A disarming strike is also described, when one ends up without a rifle in front of an armed opponent. The difficulty of this technique consist in parrying the inevitable attack from the opponent with the hand, a little stick, a knife, a bayonet taken off the rifle, etc. After that, you just have to grab the opponent's rifle while twisting it to make your opponent let go of it, using for that all the remaining resources, foot, fist, knee, anything which can injure the opponent. Once your opponent's rifle in your hands, swiftly kill him with his own gun.

The following evokes the importance of having a solid knowledge of unarmed fighting, then the ways how to train soldiers, describing the content of the lessons, the combination of strikes to teach to the men, linked with the rest of the physical training, the means to test the students'progression...

A typical bayonet fencing lesson is also described.

In the book's annexes are to be found other confrontation possibilities, such as ending up in front of a shorter or longer weapon.

The annexes also include a precise description of training modalities, of the training ground, the gear, as well as the rules to be used during tournaments and competition on the barracks grounds. 
a) Piste de combat à la baïonnette.

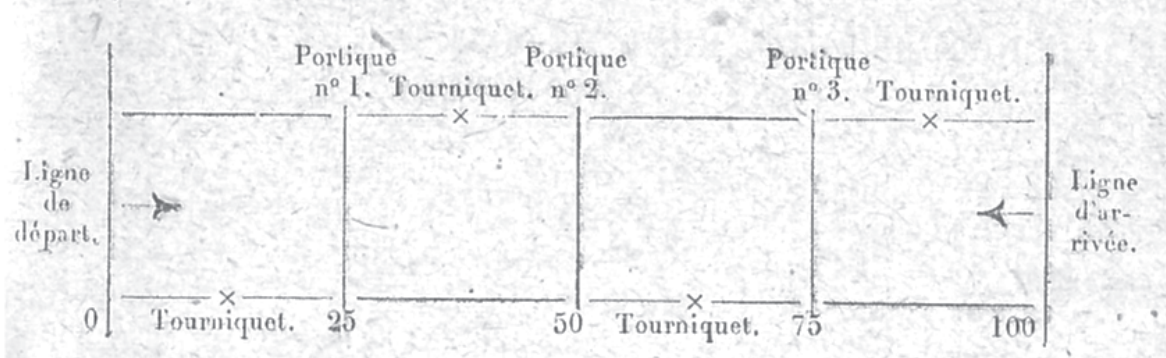

\section{Longueur : 100 mètres.}

Largeur : variable, $2 \mathrm{~m}$. 5o au moins.

Sol : aussi plat que possible.

Trois portiques à 25,50 et 75 mètres de la ligne de départ.

Quatre tourniquets, deux à droite, deux à gauche.

En outre, du matériel mobile peut y ètre ajouté pour certaines épreuves : haies, murettes de bois, escalades, sacsmannequins à terre, disques de papier à terre, etc.

Fig.329

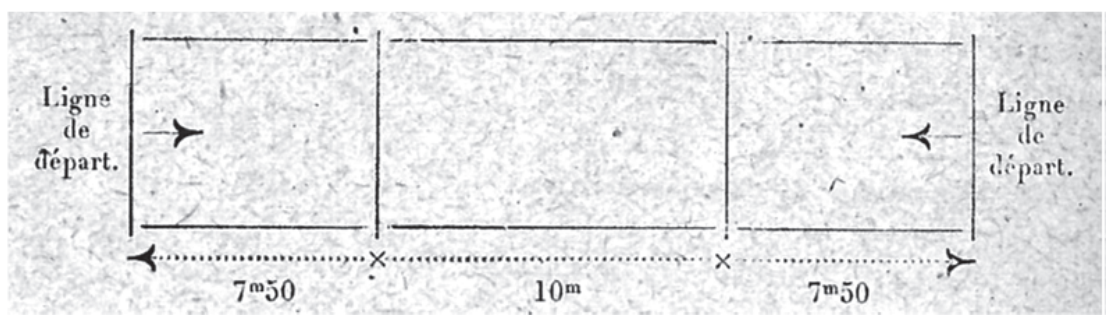

Fig.4

Figure 3 is an extract from page 55, and describes the soldiers' skills are tested or where obstacle with targets contests are organised. Figure 4 pictures the bayonet fencing ground for tournaments. It solely consists in an adapted fencing floor.

Extract from the tournament rules :

"[...] Earning points. - If no decision has been taken by ten seconds, the timer ends the fight and both contestants get both zero.

If one of the contestants steps back and steps over the 10 meters line, the fight doesn't stop, but the one who stepped back gets two points off his total score.

Points to be awarded :

${ }^{29}$ Fig 3 \& 4 extract from « Anexe IV » page 58 
4 points for any hit (point, knife or stock) reaching the torso (except for the cartridge belt), both thighs, knee included, the neck or the head, and for every attempt at handto-hand fight (not pushed till its conclusion) which could lead to a complete incapacitating;

2 points for any hit (point, knife or stock) reaching the arms or the legs (below the knee), for any glancing hit to the torso, thigh, neck or head, for any hand-to-hand grab which might lead only to a temporary incapacitating.

1 point for any glancing hits reaching the arms or the legs (below the knee).

On the first witnessed result, the instructor (or the jury's headman) shouts "Halte!". The fight stops. If there is a hand-to-hand grab, it is held so that the grab can be judged.

Doubles. - If a true double hit is on, the difference between both the hit values is given to the best hit $[. .]$.

\section{Nota bene :}

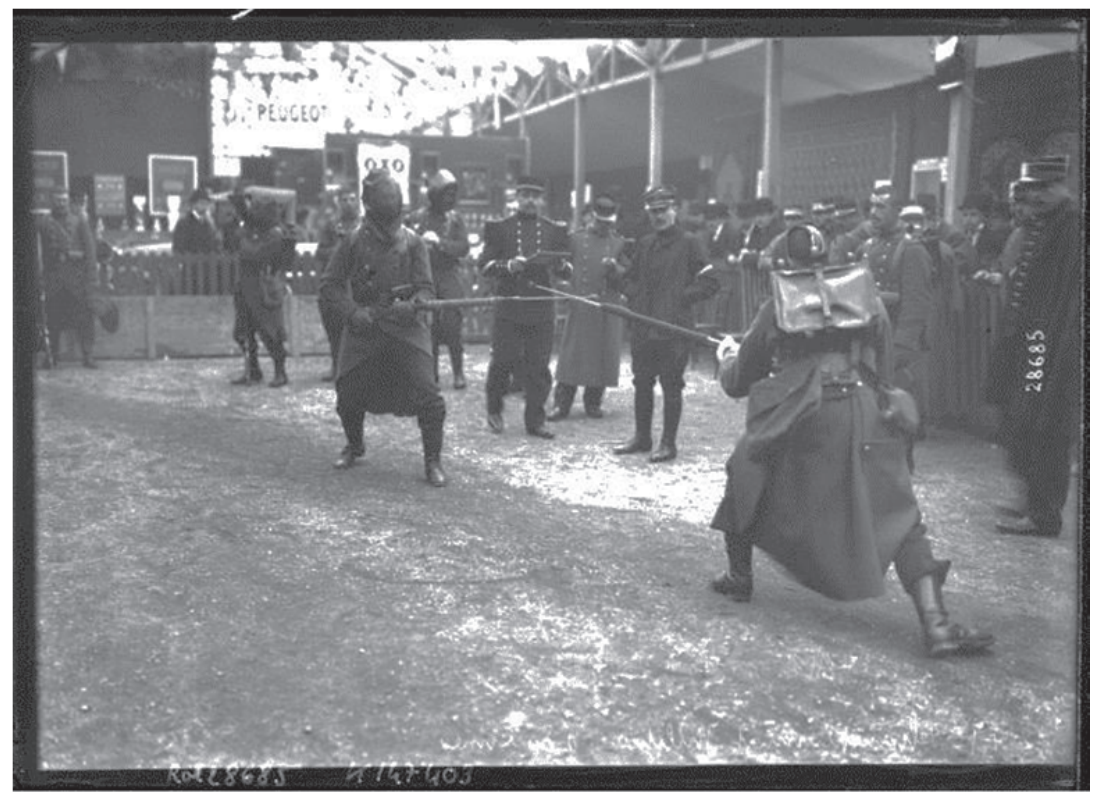

Source gallica.bnf.fr / Bibliothèque nationale de France

Photography of a bayonet fencing tournament in April 1913.30

The tournament organisation - as described in the 1918 book or its predecessors although representative from some "fighting turned into sport" of the art, still keeps a strongly developed military aspect: most of the time, soldiers spar in combat outfits,

30 From «Gallica », The OnLine Library of The Bibliothèque Nationale de France 
with realistic simulators, and a point-system which puts forward a large event of techniques, armed or not, and the credibility of the lethal aspect of the hits achieved with those techniques. The very short length of these fights encourages a compulsory swift decision-taking for the soldier (which is not necessary for the sportsman).

At the end of the day, "sport" tournament bayonet fencing is nothing but a developed form of training.

The 1918 method thus represents the epitome of the official art of the bayonet, the most evolved and most comprehensive method ever to have borne the signature of the Ministry of War, detailed as far as pure technicality is concerned, but also for the rest: description of trainings, lessons, of the qualities to be developed, which gear to use and even the applications to sport. This method is also adapted to its context of use : there can be found numerous mentions about trenches, tunnels, rough or sleeping grounds. The lessons from this leaflet offers the instructors and their students the most complete event of techniques and situations possible, and offers the soldiers the largest adaptability of its art.

\section{CAPTAINS DUBOIS AND HASSLER : TWO AUTHORS AT THE SERVICE OF THE ARMY :}

\section{1. -La Baïonnette, à la Française !, by Capitain M.Dubois, in $1916^{31}$ :}

Working for the colonial infantry, Captain Dubois was really attached to teaching bayonet fencing. The 191432 regulations, in effect when France and its allies came into War, included, according to him, a method sufficient to ensure the victory for any French tirailleur. So he wrote a book destined to his fellow instructors of the Army, in which he praised this method, and, detailing it point after point, technique after technique, he developed his subject with many a diagrams and photos, making sure that anyone could understand the slightest movement, the slightest notion from the method.

The book, which was extremely descriptive, and which was written with the severity and the very military lack of fantasy from its writer, still remains a must-read for those who would wish to learn the 1914 method. As a matter of fact, there is no clearer, no more academical, no more pedagogic way to teach a fencing method.

31 DUBOIS, M. (1916) : La baïonnette, à la française ! Techniques élémentaires. Lavauzelle, Paris. A complete transcription of this book is available on the De Taille et d'Estoc forum.

32 Ministère de la Guerre 1914 ; ibid 


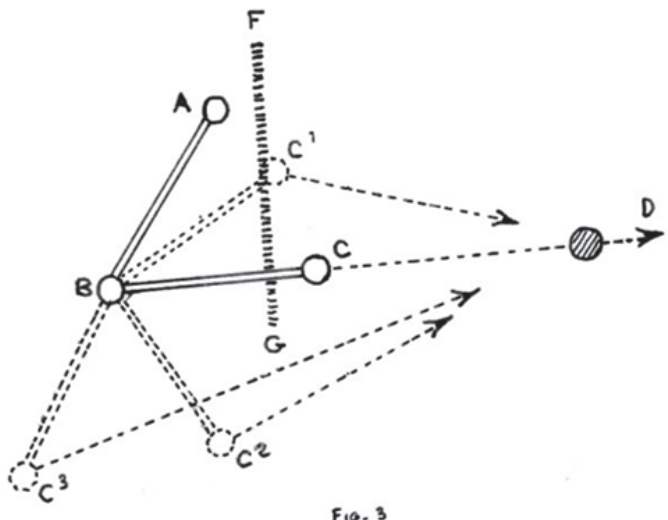

Example of diagram made by Dubois to explain, in this case, the best way to hold one's rifle to have the best penetration rate into matter.33

Dubois, also, gives some instructor "tips" : ways and means to conduct fencing lessons, training exercises, learned pieces of advice towards those who would wish to give the most efficient training.

For instance, he advises :

"The "blank" exercises which I thus recommend to avoid are those in which no objective is offered to the man. By "objective", I imply any "target" offered to his strikes, even though he cannot reach it : a tree, the instructor, a comrade. The bayonet fighter thus trains on an objective he cannot reach, exactly like, without bullets, the shooter trains, on an objective, to take aim, to let the shot go. After that, the man shoots for real, either on a dummy with his gun, or "on the wall", with a fencing rifle." (page 15)

He also explains to those concerned by his book, who are his colleagues instructors :

"We further have the rest of an unmistakable criterium of quality of our teachings : if some twenty minutes fencing lesson is as it should have been, our men, breaking ranks for rest, have for first gesture, a gesture of aggression." (page 17)

This author, all along his book, gives a developed comment on the 1914 method, nevertheless, nothing in his handbook, as far as the method itself is concerned, has been invented, everything has existed before, it is solely described in more pedagogic terms, and illustrated by diagrams or photographies. Which is not the case of the authors coming afterwards.

33 Page 8, chapter I «Principe généraux » 


\section{Rosalie or the too small holes}

Following the armistice, the modifications in Geneva Convention forbade the use of triangular, round or cross-pointed bayonets, owing to the nature of the wounds inflicted by those weapons: as a matter of fact, the gashes being too small, the outer wounds had a tendency to close too fast, and thus to bide the possible haemorrhages, or contain them inside the body.

We can remark that the French blades of the time, the model 1886, were thus forbidden, but so were the german bayonets, because their notched blades were judged too barbaric and likewise forbidden by the same Convention...

\section{L'arme blanche dans la grande Guerre, Méthode simplifiée de Baïonnette, by Captain Hassler et Émile André, in $1916{ }^{34}$}

Captain Hassler, following the same ideals than his counterpart in the colonial infantry, Dubois, decided just like him, to publish a commentary about the 1914 method. With this aim, he associated with the famous Emile André, a celebrated author, acknowledged by the world of martial arts, self-defense and sport, writer of the already famous l'art de se défendre dans la rue, le jeu de l'épée, and who was used to working with the military, which he had experimented with, for the writing of l'escrime du sabre à cheval, with adjudant Alessandri ${ }^{35}$.

Those two "professionals" would thus write this book together, which would be recommended by monsieur Humbert, Meuse senator :

- They would start, since this was a time of patriotic enthusiasm, by praising the merits of this art, especially in the hands of the French soldiers, and the virtues it brings to the soldier and the Army, on a morale basis, but also on a level of self-confidence, etc. In this part, they also describe that, especially at the beginning of the War, the so French "bayonet culture" would play against soldiers who were deceived - taken away by their skirmisher bayonet fencer enthusiasm - by a feigned German retreat and were wiped out by a hidden machine gun... Nevertheless, these authors recognize the essential use of blade fighting in the no-man's-land, or in the case of an attack against a position, or in the case of "clearing" an enemy's trench. They explain that some strikes taught to the soldiers, such as the "Lancez", albeit being efficient in tournament or courteous duels, are put aside by the soldiers, whom, in the heat of the action, prefer to use more secured strikes such as the "Pointez", which doesn't require to let go of one hand...

34 - HASSLER \& ANDRE, E. (1916) : L'arme blanche dans la grande Guerre, Méthode simplifiée de Baïnnette. Floury, Paris.

35 - ANDRE, E. (1899) : L'art de se défendre dans la rue (résumé des partie les plus simples et les plus pratiques de la boxe, de la lute, du maniement de la canne, etc, Flammarion, Paris.

- ANDRE, E. (1887) : Le jeu de l'épée (méthode de Jacob),Ollendorff, Paris.

- ALLESSANDRI, L.A. \& ANDRE, E. (1899) : L'escrime du sabre à cheval, Flammarion, Paris. 


\section{The last One}

The last (official) bayonet charge of the French Army took place in 1951, during the Korean War, by the French UNO bataillion, later called "Korean Bataillion", led by Lieutenant-Colonel Raoul-Vernrey aka "Monclar".

On February 1, 1951, the bataillion was surrounded in Twin Tunnels, near Chipyong $\mathrm{Ni}$, by the $125^{\text {th }}$ division of Chinese Volunteers, nearly 30kms abead the Allies Front Line. It was then that the French launched a victorious bayonet counter-strike to get clear of their being surrounded. This assault put the $125^{\text {th }}$ Chinese Division out of fight, and would bring a commendation in the U.S. General Ridgway, commanding officier of the United Nations forces, will comment upon this: "That will remind all the units that this instrument was not only invented to open food cans."

- After that, they tangle the technical part, explaining the interest of flexing exercises, then, like Dubois ${ }^{36}$, quoted earlier on, they define step by step the techniques of the 1914 method. If our good Captain of the Colonial Infantry just quotes the method without adding anything, they gladly develop their subject, explaining how to link possible strikes with the different attacks, guards or parades combinations, illustrating their words with many photographs. They also choose not to waste time on the strikes which are the less applicable to the real situations, according to them, which is to say the "Pointez" variations, the "oppositions" (which are left aside, in favor of "battement", especially). They also describe the left or right "parades" in a wider and more exaggerated way than Dubois, who saw it as a very short movement, barely leaving the line of attack : they show a movement strongly sweeping away the opponent's weapon, bringing the point completely on the side (left or right) of the defender. These sayings were illustrated by one of the many photographies which can be found in this handbook.

Their commentary/explanation of the 1914 method finishes on an example of typical lesson which can be given to the soldiers, approaching the different sides of this fencing with a logical progression.

- At last, they close their book on chapter called "Special Cases", in which they present and explain a few techniques aimed at "contextualising" the 191437 method, adapting it to the trenches situation. As a consequence, these are ways to kill an opponent situated in a trench, whereas the the fencer is on the battlement. In those special cases are also mentioned the possible fighting with a horseman or a footsoldier armed with a saber :

In a trench, it is easy to kill a man who is below you, with a simple "battement" from the opponent's weapon, whose handling is constrained by

36 DUBOIS, 1916 ; ibid

37 Ministère de la Guerre 1914 ; ibid 
the narrowness of the trench. If the opponent resists, , you should then drop to your knees on the battlement, to offer a smaller target, and sting his face, still visible over the trench.

In front of a sabre-wielder, André and Hassler recommend the following techniques: a parade or a "battement", made irresistible by the weight difference, then a "Pointez", making sure that the saber-wielder does not grab the point of the bayonet.

In front of a horseman, aim for the horse first, to make the rider lose control, then, jumping on one side - left or right - aim for the man...

The book ends on a military march song about the bayonet, simply entitled "A la Baïonette!" and which was published in the "Le Matin" newspaper in August 1914.

\section{TO CONCLUDE...}

As previously shown, between the regulation of 1904 and its one guard, two attacks and three parries, and that of 1918 with four guards, attacks, parries, ripostes, beats, body slams and so forth, "official" methods of bayonet fighting underwent major evolutions. This first took place on a qualitative level, thanks to the update of the 1904 method, then shortened and truncated by the lack of interest of the governing authorities at the beginning of the XXth century, convinced as they were that the technological revolution brought about by the infantry rifle, more precise, faster to load and with a longer range would bring this art to an end. Also, at the same time the new regulations of 1914 brought a renewed efficiency and versatility to bayonet fencing, a contextual evolution appeared thanks to André \& Hassler's book ; then again, later, with the method of 1917-18, covering the new situations that a soldier was meant to encounter and use on the battlefield, such as disarmament techniques, empty-hand parries, defense of a trench...

The rapid evolution of ballistic armament resulting in increased accuracy, rate of fire, damage and range certainly resulted in the abandonment of several military practices and techniques, such as the cavalry charge, formerly devastating and righteously dreaded, but which found its limits in a battlefield made of impassable maze of trenches, shell holes, mine fields and barbed wire. But the bayonet was not one of them, and indeed not only carried on through the entire war, but also was kept in use many years afterward. It proved its usefulness on a martial and military level, as close combat situations were always present, even in trenches and shell holes, but also on a psychological level, albeit little mentioned by the various authors. Yet this latter aspect was an important factor : in close combat, a trooper confident in the superiority of his skills, or at least their effectiveness, will know how to overcome fear at the right moment. Thus, although strategists and military thinkers of the beginning of the XXth century heralded the upcoming end of this martial art, World War I endowed it with a new life. In fact, the method of 1918 shows a clear superiority to that of 1904, in use 
when the War started : complete, better defined and far more adapted to the context and even usable as a sport!

\section{BIBLIOGRAPHY}

In alphabetical order :

ALLESSANDRI, L.A. - ANDRE, E. (1899) : L'escrime du sabre à cheval. Ernest Flammarion, Paris. pp.62.

AUBRY, B. (2001) : Il était une fois la Baïonnette. Bulletins n¹7 et 18 de la revue de L'AFCB. pp.2.

AZEMAR, L.M.M. baron d'. (1859) : Combat à la baïonnette, théorie adoptée en 1859 par l'armée d'Italie, commandée par sa majesté - l'Empereur Napoléon III. Leneveu, Paris.

BARDIN, E.A. (1813) : Manuel d'infanterie, ou Résumé de tous les réglements, décrets, usages, renseignements propres aux sous-officiers de cette arme. Magimel, Paris.

DE BREZE. (1779) : Réflexions sur les préjugés militaires. Reycends.

CHAPÎTRE, F. (1856) : Gymnastique militaire, escrime à la Baïonnette. Renier, Bruxelles

COCHET, F \& PORTE, E. (2008) : Dictionnaire de la Grande Guerre 1914-1918. R. Lafont, Paris. Article « Baïonnette».

CORTHAY, A. (1893) : Petit traité d'escrime à la baïonnette. Alcan-Levy, Paris.

DUBOIS, M. (1916) : La baïonnette, à la française ! Techniques élémentaires. Lavauzelle, Paris.

EVANS, R.D.C. (2000-2004) : A bibliography of the bayonet, Bayonet studies series.

GIRARD, P. J. F. (1740) : Traité des armes. dédié au Roy, Pierre de Hondt, La Hate. pp.147.

GRISIER, A. (1854) : Les armes et le duel. Dentu, Paris. pp.501, pp.101 \& pp.123.

GUIBERT, J.A.H. (1805) : Cuvres militaires de Guibert publiées par sa veuve, tome premier. Magimel, Paris. pp.175.

HASSLER \& ANDRE, E. (1916) : L'arme blanche dans la grande Guerre, Méthode simplifiée de Baïonnette. Floury, Paris.

MERY, C. - RENOUX, P. - ADAM, G. (2005) : Les baïonnettes militaires françaises. Mémento. Crépin-Leblond, Chaumont.

Ministère de la Guerre? (1917) : Instruction pour le combat à la baïonnette et le lancer de grenade. Lacour, Besançon.

Ministère de la Guerre. (1870) : Manœuvres de l'infanterie. Ropiteau, Dijon.

Ministère de la Guerre. (1910) : Manuel d'instruction militaire. Chapelot, Paris.

Ministère de la Guerre. (1926) : Manuel du gradé d'Infanterie. Lavauzelle, Paris.

Ministère de la Guerre. (1904) : Décret du 3 décembre 1904 portant règlement sur les manœuvres de l'infanterie. Berger Levraut, Paris.

Ministère de la Guerre. (1918) : Entraînement physique du combattant, du 1er septembre 1918, Imprimerie Nationale, Paris.

Ministère de la Guerre. (1870) : Nouveau manuel de la Garde Nationale sédentaire, contenant les lois des 10 août 1870, 15 mars, 20 mai et 12 juin 1850, l'école du soldat, l'école de peloton, la manœuvre du fusil Chassepot, du fusil dit à tabatière,du fusil à percussion. Barbou, Limoge. 
Ministère de la Guerre ? (1849) : Pas gymnastique. Escrime à la bayonette et supplément à l'école des tirailleurs en usage aux chasseurs d'Orléans et dans plusieurs corps de l'armée. Blot, Paris.

Ministère de la Guerre. (1920) : Règlement provisoire de manœuvre d'Infanterie du 1er février 19201 ère partie. Imprimerie Nationale, Paris.

Ministère de la Guerre. (1914) : Règlement de manœuvre d'infanterie du 20 avril 1914. Fournier, Paris.

Ministère de la Guerre. (1914) : Règlement d'éducation physique du 21 janvier 1910, mis à jour le 1er juin 1914. Lavauzelle, Paris.

Ministère de la Guerre. (1894) : Règlement du 29 juillet 1884 modifié par décision du 15 avril 1894 sur l'exercice et les manœuvres de l'infanterie. Baudoin, Paris.

Ministère de la Guerre. (1875) : Règlement du 12 juin 1875 sur les manœuvres de l'infanterie ; avec un rapport à $\mathrm{m}$. le Ministre de la guerre. T.1-2. Imprimerie Nationale, Paris.

Ministère de la Guerre. (1902) : Règlement provisoire sur les manœuvres de l'infanterie du 8 octobre 1902, Chapelot, Paris.

Ministère de la Guerre. (1791) : Règlement concernant l'exercice et les manœuvres de l'infanterie : du 1er août 1791. Belin, Paris.

Ministère de la Guerre. (1860) : Règlement sur l'exercice et les manœuvres des régiments d'infanterie, de carabiniers et de chasseurs à pied. Sieron, Gand.

Ministère de la Guerre. (1792) : Règlement concernant l'exercice et les manœuvres de l'infanterie : du 1er août 1791. Laillet, Paris.

MULLER, (1835) : Maniement de la baïonnette, appliqué à l'attaque et à la défense de l'infanterie. Moreau, Paris.

NIDVINE, S. (1907) : La Baïonnette. Chapelot, Paris.

PINETTE, J. (1837) : Ecole du tirailleur ou maniement de la baïonnette appliqué aux exercices et manœuvres de l'infanterie. Gauthier-Laguionie, Paris.

POSSELIER, A.J.J. « Gomard » (1847) : L'escrime à la baïonnette ou l'école du fantassin. Dumaine, Paris.

SOYER, J.B. (1846) : Exercices et manœuvres de l'infanterie, classés et développés par M. Soyer. Dumaine, Paris.

VON SELMNITZ, E. (1840) : De l'escrime à la baïonnette, ou, instruction pour l'emploi du fusil d'infanterie comme arme d'attaque et de défense, traduction par MERJAY de Die bajonetfechtkunst oder lehre des verhaltens mit dem infanterie-gewerhre. Petit, Bruxelles. 